\title{
Analysis of Higher Education GER - A Study for West Bengal and Orissa
}

\author{
Tushar Kanti Ghara ${ }^{1}$ \\ ${ }^{1}$ Joint Director of Public Instruction \& State Nodal Officer, All India Survey on Higher Education \\ Government of West Bengal, Bikash Bhavan, Salt Lake City, Kolkata 700091
}

\begin{abstract}
The Higher Education status is still derived by the value of GER (Gross Enrollment Ratio). The districts of West Bengal and Orissa, India have been compared taking data from National Survey (AISHE). The districts are also compared and grouped.
\end{abstract}

Keywords: All India Survey on Higher Education, GER, Cluster Analysis, Ranking

\section{INTRODUCTION}

Gross Enrolment Ratio (GER) is the total enrolment in a specific level of education, regardless of age, expressed as a percentage of the eligible official school-age population corresponding to the same level of education in an year. The purpose is to show the general level of participation in a given level of education. It indicates the capacity of the education system to enroll students of a particular age group. It indicates the extent of over-aged and under-aged enrolment. It is the number of pupils (or students) enrolled in a given level of education regardless of age by the population of the age group which officially corresponds to the given level of education, and multiply the result by 100 .

GER $=\mathrm{E} * 100 / \mathrm{P}$ where GER is Gross Enrolment Ratio at level of education in the year, $\mathrm{E}$ is the Enrolment at the level of education in the year and $\mathrm{P}$ is the Population in age group (18-23 lbd)(last birth day) which officially corresponds to the level of education in the year. We are to know the total enrolment for a given level of education, population of the age group (18-23 years) corresponding to the specified level (higher education). All India Survey on Higher Education (AISHE) gives the enrolment data in higher education. Population censuses or estimates for higher education population obtained from the reports of Census Bureau for all the years based on last census data. A high GER generally indicates a high degree of participation, whether the pupils belong to the official age group or not. A GER value approaching or exceeding $100 \%$ indicates that a country is, in principle, able to accommodate all of its susceptible population, but it does not indicate the proportion already enrolled. The achievement of a GER of $100 \%$ is therefore a necessary but not sufficient condition for enrolling all eligible population in higher education institutes. The GER exceeds $90 \%$ for a particular level of education, the aggregate number of places for pupils is approaching the number required for universal access of the official age group. However, this is a meaningful interpretation only if one can expect the under-aged and over-aged enrolments to decline in the future to free places for pupils from the expected age group. GER at each level of education should be based on total enrolment in all types of educational institutions, including public, private and all other institutions that provide organized educational programmes. GER can exceed $100 \%$ due to the inclusion of over-aged and under-aged pupils/students because of early or late entrants, and grade repetition. In this case, a rigorous interpretation of GER needs additional information to assess the extent of repetition, late entrants, lateral entrants, etc.

The International Standard Classification of Education(ISCED) is designed to serve as a statistical framework for assembling, compiling and presenting comparable indicators and statistics of education both within individual countries and internationally. It presents standard concepts, definitions and classifications. ISCED covers all organized and sustained learning opportunities for children, youth and adults including those with special needs education, irrespective of the institution or entity providing them or the form in which they are delivered. Gross Enrolment Ratio (GER) in Higher education in India is calculated for 18-23 years of age group. Total enrolment in higher education, regardless of age, expressed as a percentage to the eligible official population (18-23 years) in the given period. Data includes details on gender wise gross enrolment ratio in higher education for all categories, SC and ST for the states West Bengal and Orissa. The same have also been calculated for the district of the states. 


\section{DATA}

Ministry of Human Resource Development has endeavoured to conduct an annual web-based effort called All India Survey on Higher Education (AISHE) since 2011-12. The survey covers all the institutions in the country engaged in imparting of higher education. Data is being collected on several parameters such as teachers, student enrolment, programmes, examination results, finance, scholarship \& stipend, infrastructure, etc.. Indicators of educational development such as Institution Density, Gross Enrolment Ratio, Pupil-teacher ratio, Gender Parity Index, Per Student Expenditure will also be calculated from the data collected through AISHE. These are useful in making informed policy decisions and research for development of education sector. The AISHE is now an annual event. Based on AISHE database, in this paper, attempt has been made to quantify the development in higher education by framing GER for the districts of West Bengal and Orissa. The ranking based on GER has been made. It is further attempted to find the clustering among the districts of West Bengal and Orissa.

\section{ANALYSIS}

MHRD published in its report, the estimates of population for the years 2011, 2012, 2013, 2014, 2015 $\& 2016$ in the age group 18-23 years. Based on the estimated total population in the age group 18-23 years, the GER of the districts are estimated as described in Ghara (2016). GER's have been calculated separately for total, female and male and for the states West Bengal and Orissa along with the districts. The ranks of the districts have been obtained based on their GER values. The trend are almost similar over the years for both the states. It is observed that for West Bengal and Orissa, in general GER-values are increasing over the year for each of the districts. It is greater for male as compared to female for all the districts and over the year.

Table 1.1 showing the ranks of the districts ( GER) 2016 for West Bengal

\begin{tabular}{|l|r|r|r|}
\hline District & Total & Male & Female \\
\hline Bankura & 15 & 15 & 15 \\
\hline Barddhaman & 5 & 7 & 5 \\
\hline Birbhum & 6 & 4 & 7 \\
\hline Dakshin Dinajpur & 8 & 10 & 6 \\
\hline Darjiling & 3 & 5 & 3 \\
\hline Haora & 18 & 18 & 17 \\
\hline Hugli & 4 & 6 & 4 \\
\hline Jalpaiguri & 11 & 16 & 8 \\
\hline Koch Bihar & 12 & 14 & 11 \\
\hline Kolkata & 1 & 1 & 1 \\
\hline Maldah & 13 & 13 & 13 \\
\hline Murshidabad & 14 & 11 & 16 \\
\hline Nadia & 2 & 2 & 2 \\
\hline North Twenty Four Parganas & 7 & 3 & 10 \\
\hline Paschim Medinipur & 9 & 8 & 9 \\
\hline Purba Medinipur & 16 & 17 & 14 \\
\hline Puruliya & 10 & 9 & 12 \\
\hline South Twenty Four Parganas & 17 & 12 & 18 \\
\hline Uttar Dinajpur & 19 & 19 & 19 \\
\hline
\end{tabular}

Table 1.2 showing the ranks of the districts ( GER) 2016 for Orissa

\begin{tabular}{|l|r|r|r|}
\hline District & Total & Male & Female \\
\hline Anugul & 8 & 6 & 14 \\
\hline Balangir & 21 & 19 & 22 \\
\hline Baleshwar & 3 & 2 & 3 \\
\hline Bargarh & 24 & 23 & 20 \\
\hline Baudh & 27 & 25 & 27 \\
\hline Bhadrak & 7 & 12 & 6 \\
\hline Cuttack & 2 & 3 & 2 \\
\hline Debagarh & 25 & 26 & 23 \\
\hline Dhenkanal & 5 & 5 & 8 \\
\hline
\end{tabular}




\begin{tabular}{|l|r|r|r|}
\hline Gajapati & 15 & 8 & 21 \\
\hline Ganjam & 10 & 9 & 11 \\
\hline Jagatsinghapur & 18 & 27 & 13 \\
\hline Jajapur & 12 & 13 & 10 \\
\hline Jharsuguda & 20 & 22 & 17 \\
\hline Kalahandi & 26 & 24 & 26 \\
\hline Kandhamal & 17 & 17 & 16 \\
\hline Kendrapara & 11 & 18 & 7 \\
\hline Kendujhar & 19 & 20 & 18 \\
\hline Khordha & 1 & 1 & 1 \\
\hline Koraput & 23 & 15 & 25 \\
\hline Malkangiri & 29 & 29 & 29 \\
\hline Mayurbhanj & 4 & 7 & 5 \\
\hline Nabarangapur & 30 & 30 & 30 \\
\hline Nayagarh & 16 & 16 & 15 \\
\hline Nuapada & 28 & 28 & 28 \\
\hline Puri & 6 & 11 & 4 \\
\hline Rayagada & 14 & 4 & 24 \\
\hline Sambalpur & 9 & 10 & 9 \\
\hline Subarnapur & 22 & 21 & 19 \\
\hline Sundargarh & 13 & 14 & 12 \\
\hline & & &
\end{tabular}

It is being observed that 'Kolkata' in one group dominates all other 18 districts for West Bengal and 'Khordha' in one group dominates all other 29 districts for Orissa. It can also be stated for West Bengal 'Kolkata', 'Nadia' \& 'Darjeeling' show more tendency to accessibility towards higher education enrolment in one cluster as compared all other 16 districts in other cluster. The same for Orissa 'Khordha', Çuttack', Baleshwar', 'Puri', 'Mayurbhanj' and 'Dhenkanal' show more tendency towards higher education enrolment in one cluster as compared to all other 19 districts in other cluster. Only about $15.8 \%$ districts have GER above 20.0, 78.9\% districts have GER between 10.0 and 20.0 and only 5.3\% districts have GER below 10.0 for West Bengal. In case of Orissa, 20.0\% districts have GER above 20.0, 63.3\% districts have GER between 10.0 and 20.0 and $16.7 \%$ districts have GER below 10.0. Considering the indicator enrolment per one lakh of concerned population (CPI), it is maximum for the district 'Uttar Dinajpur' and minimum for the district 'Kolkata' in West Bengal; it is minimum for 'Khorbha'and maximum for 'Mabrangapur' in Orissa. It is also observed that enrolment per college (ECI) (on the average and taking all colleges), all the districts in Orissa has low ECI as compared to the districts in West Bengal; in West Bengal it is maximum for the district 'Úttar Dinajpur'and minimum for the district 'Kolkata' whereas it is maximum for the district 'Debagarh'and minimum for the district 'Gajapati'in Orissa.

\section{CONCLUSION}

AISHE database has been used to calculate GER for the districts of West Bengal using population estimates. Ranking of the districts has also been made. Clustering has been derived to see the homogeneity among districts. 'Kolkata'is the districts with highest accessibility for West Bengal and 'Khordha'for Orissa. 'Bankura' is the least accessible district. West Bengal has increasing trend in GER from 13.64 in 2011 to 17.66 in 2016. The percentage of districts with low GER (below 10.0) is higher in Orissa as compared to $5.3 \%$ in West Bengal.

\section{REFERENCES}

[1] All India Survey on Higher Education, MHRD, Govt. on India: www.aishe.gov.in

[2] Bhandari, P(2012), Refining State Level Comparisons in India, Working Paper Series, Planning Commission, India

[3] Educational Statistics at a glance(2014), MHRD, Government of India

[4] Everitt, Brian (2011). Cluster analysis. Chichester, West Sussex, U.K: Wiley

[5] Global Monitoring Report (2006), Planning Commission of India, Govt. of India

[6] Global Education Monitoring Report(2015), The Education for All Development Index

[7] Mehta A C,(2012), Indicators of Educational Development with focus on elementary education : Concept and Definitions

[8] Sarkar, D and Jhingran, D (2012), Educational Development Index, Working Paper Series, MHRD, Govt. of India 
[9] 2009 Education Indicators Technical Guidelines - UNESCO Report

[10] Census of India 1981. Provisional Population Totals, Paper 2: Rural-Urban Distribution, Office of the Registrar General and Census Commission, India, New Delhi

[11] Census of India 2011. Provisional Tables, Paper 2, Office of the Registrar General and Census Commission, India, New Delhi

[12] Ghara, T.K. 2016. Analysis Of Higher Education GER - A Study For West Bengal, IOSR Journal of Humanities And Social Science, Volume 21, Issue 11, Ver. 3, 13-19, www.iosrjournals.org. 